\title{
Toughness Properties of Nanostitched and Nanoprepreg Carbon/Epoxy Materials
}

\author{
Bilisik $\mathrm{K}^{1 *}$, Erdogan $\mathrm{G}^{1}$, Karaduman $\mathrm{N}^{2}$, Sapanci $\mathrm{E}^{3}$ and Gungor $\mathrm{S}^{3}$ \\ ${ }^{1}$ Department of Textile Engineering, Erciyes University, Turkey \\ ${ }^{2}$ Akdagmadeni Vocational High School, Bozok University, Turkey \\ ${ }^{3}$ ROKETSAN Industries, Elmadag-Ankara, Turkey
}

Submission: September 22, 2017 Published: November 10, 2017

"Corresponding author: Bilisik K, Department of Textile Engineering, Faculty of Engineering, Erciyes University, 38039 Talas-Kayseri, Turkey, Email: kadirbilisik@gmail.com

\section{Introduction}

Textile composites have been used in various spaceaerospace, ballistic and medical areas due to their high stiffness to weight ratio and damage tolerance properties. Recently, nanosphere, single wall or multiwall tubes were employed in fiber based composites by dispersing the nano in the resin using various techniques [1]. Single wall carbon nanotubes (SWCNTs) or MultiWall Carbon Nano Tubes (MWCNTs) have become an important industrial material especially in the use of advanced composites [2]. This provided a significant improvement in mode-I fracture toughness and tension-bearing [3,4]. The objective of this study was to develop nano stitching/nano prepreg carbon/epoxy composites and to examine the fracture toughness of those structures.

\section{Materials and Methods}

\section{Nanostitching/nanoprepregcarbon/epoxy preform and composite}

Polyacrylonitrile (PAN) carbon woven fabrics (Spinteks A.S., TR) were used to make nanopreform. The multiwall carbon nanotubes (MWCNTs, Nanothinx, GR) were selected based on compatibility with the carbon fabric. Basically, three types of carbon structures were developed: 1) base (CTU, CSU); 2) base/nano (CTU-N, MWCNTs prepreg; CSU-N, MWCNTs prepreg); 3) stitched/nano (CT-CS-N, PAN carbon nanostitched/ nanoprepreg; CT-TS-N, para-aramid nanostitched/nanoprepreg; CS-CS-N, PAN carbon nanostitched/nanoprepreg; CS-TS-N, para-aramid nanostitched/nanoprepreg). MWCNTs (0.03125, \%wt., Nanothinx, GR) were added to epoxy resin (Araldite LZ 5021, Biester feld Spezialchemie GmbH, DE) after series of magnetic mixing and ultrasonic mixing and vacuuming to get homogeneous dispersion. The matrix was applied to the carbon fabric and stitching yarnsto make nano prepreg fabric and nano stitching yarn, respectively. The four layered prepregnanocarbon preform was stitched by carbon or para-aramid nanostitching yarn. The nanostiched/nanoprepreg preform was consolidated by using the compression molding.

\section{Mode-I interlaminar fracture toughness $\left(G_{i c}\right)$ test}

The mode-I interlaminar fracture toughness (GIC) of the base, base/nano, and stitched/nano structures was measured using the Double Cantilever Beam (DCB) test specimen. We followed ASTM Standard D5528-01.The delaminated areas and damaged surfaces of the composite sample were examined by a scanning electron microscope (SEM, LEO 440® model, UK).

\section{Results and Discussion}

We started by selecting $0.5 \%$ (weight \%) ratio for the MWCNTs as an initial condition. Later on, a large agglomeration (about 200-300 microns) of nanotubes was found in the epoxy. Extensive studies were conducted to decrease the size of the agglomeration of the nanotubes. For this reason, we decreased the MNCNT ratio and increased the stirring time in ultrasonic mixing. Therefore, the size of the agglomeration of carbon nanotubes decreased to 30-80 microns in the epoxy (Figure 1(a)). The MWCNT added epoxy was applied to the stitching yarn (Figure 1(b)) and fabric (Figure 1(c).

\section{Mode-I fracture toughness results}

The average fracture toughness GIC max (BT) and (MBT) values of the stitched/nano structures showed an almost 3 fold (283\%) and over a 2 fold (225\%) increase compared to the base or base/nano structures (Figure 2), respectively. It was realized that stitching and nano increased the fracture toughness GIC max of all the stitched/nano composites. At the declamination front, minor biaxial fiber bridging (warp/filling) in the in-plane direction was obtained to support declamination resistance. The nanostitching yarn under the declamination load was stressed 
and fiber bridging occurred in the out-of-plane direction until the nanostitching yarns were broken in their straight portion.

Around the nanostitching yarn region, crack propagation was severely arrested.

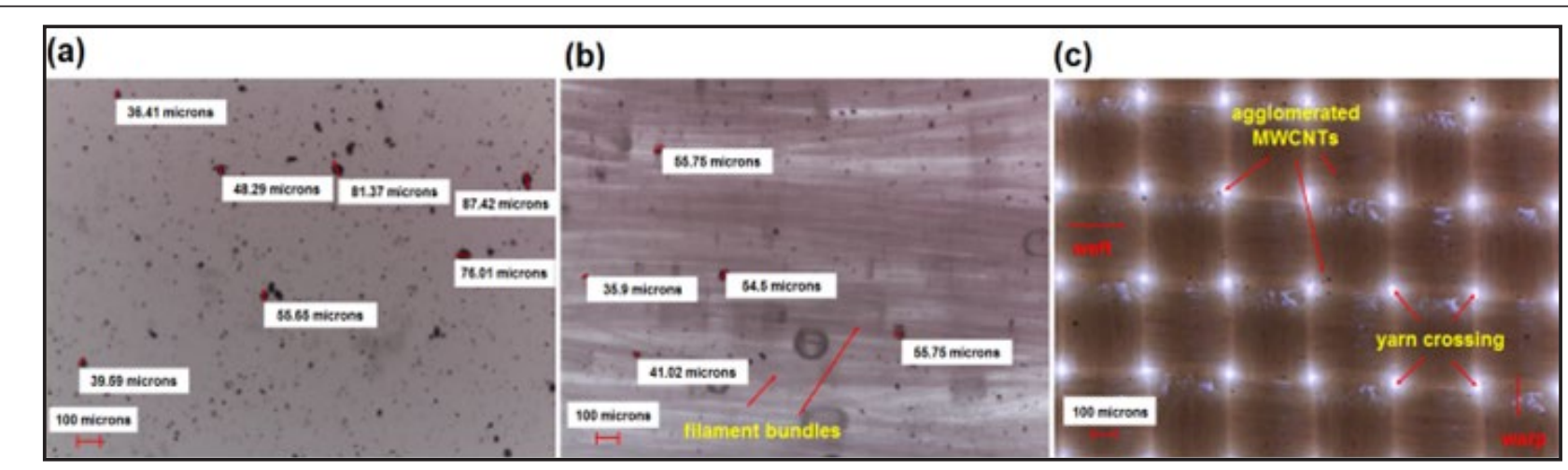

Figure 1: (a) Nanoepoxy resin; (b) nanostitchingyarn; (c) nanoprepregfabric surface (Optic microscope, magnification x4, x4, x1, respectively).

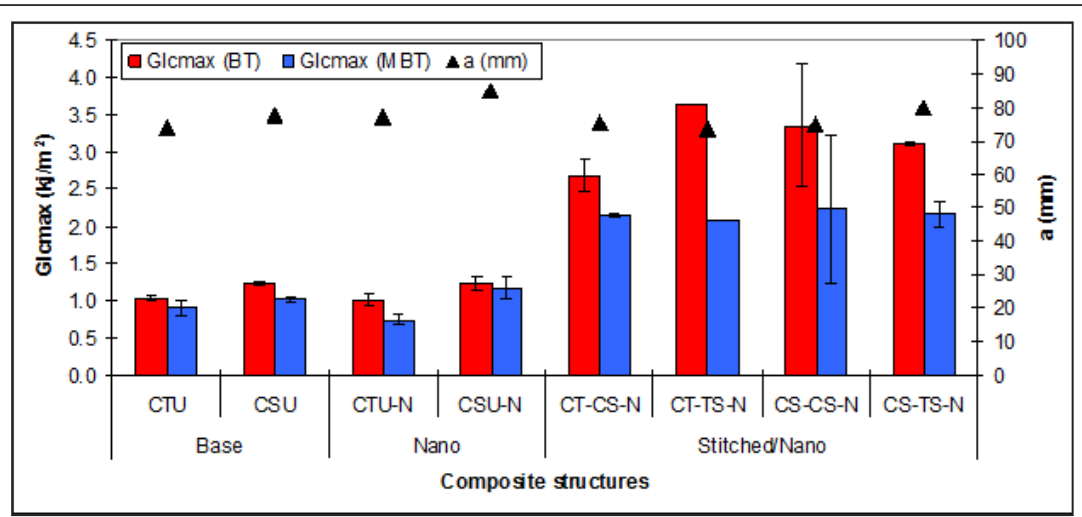

Figure 2: Interlaminar fracture toughness $\left(\mathrm{G}_{\mathrm{Icmax}}, \mathrm{kj} / \mathrm{m}^{2}\right)$ and crack length $(\mathrm{a}, \mathrm{mm})$ results for nanostitched/nanoprepreg carbon/epoxy composites.

\section{Failure after DCB test results}

Uniform declamination growth was observed parallel to the mid-plane warp near to the mid-plane of the base (CSU and CTU) structures (Figure $3(\mathrm{a}-\mathrm{c})$ ). However, minor rough crack growth was observed in the filling and probably extended in the filling direction. Both the base and base/nano structures had a sharp crack tip. Long smooth crack propagation was achieved near to the mid-plane of the stitched/nano (CS-TS-N) composites in the warp directions. Short length rough crack propagation was identified in the filling as a form of filament/filament splitting in the filling direction. Both structures had a sharp crack tip in the declamination front (Figure 4(a-b)).

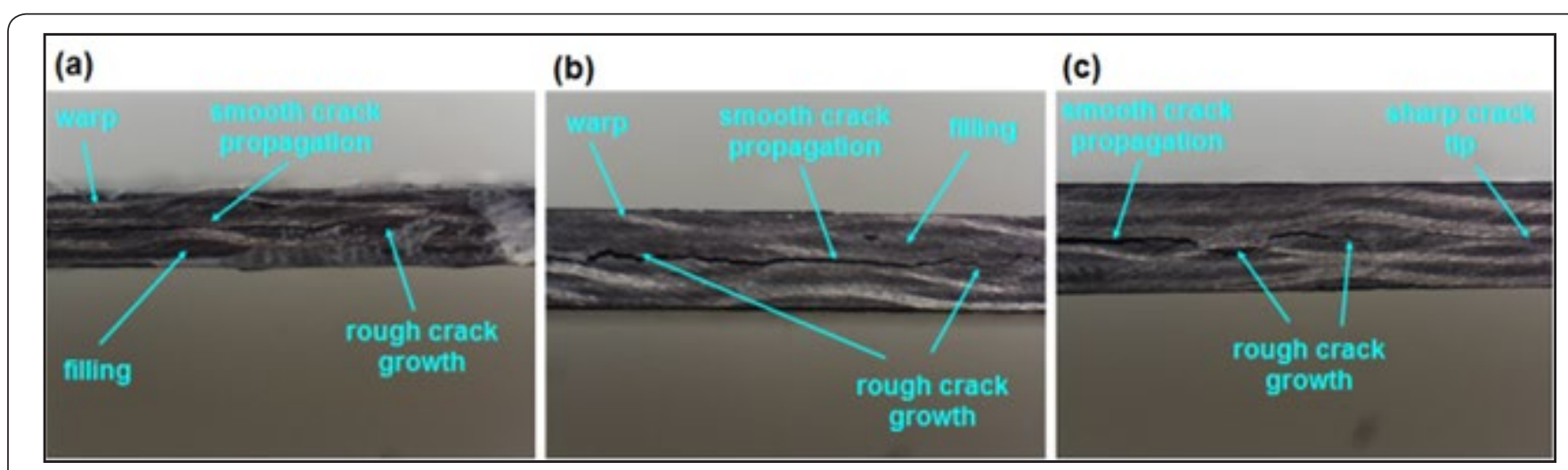

Figure 3: (a) Delamination growth failure in CSU; (b) crack failure in CTU; (c) delamination failure in CSU-N (optical microscope, magnification $\times 6.7)$. 

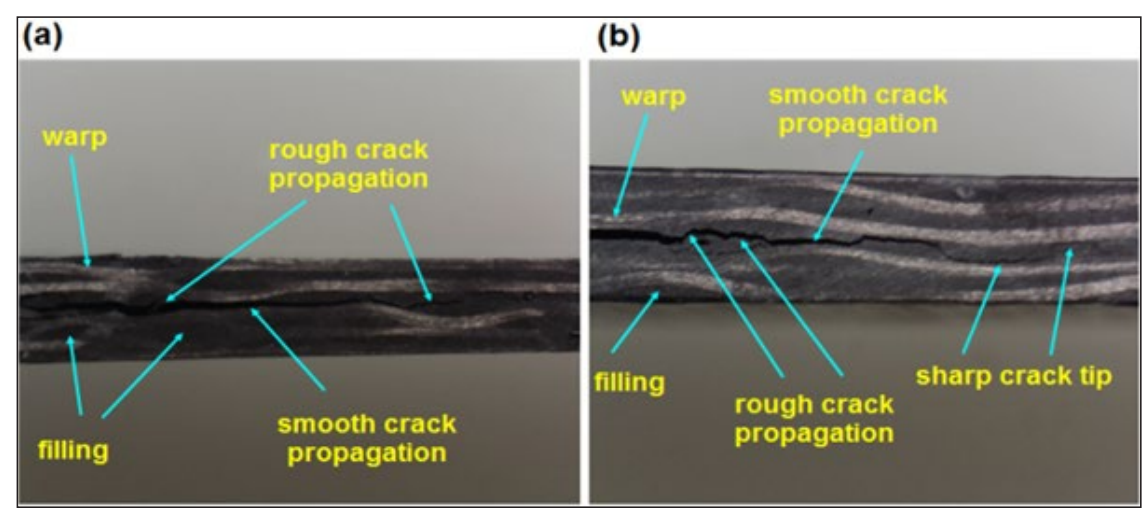

Figure 4 : (a) Delamination growth failure in CSU; (b) crack failure in CTU; (c) delamination failure in CSU-N (optical microscope, magnification $\times 6.7)$.

Beam arms failure at the declamination front of stitched/ nano (CS-TS-N) structures was identified. Under fracture toughness load, declamination crack growth was arrested by the fiber bridging of the nanostitching yarns in the out-of-plane direction. When the nanostitching yarn strength was well above the top layer structure strength, "beam arms failure" occurred in the top layer which was to some extent related to the bending strength (Figure 5(a)). Most of the warps next to the interlocking loops of the paraaramid nanostitching yarn were simultaneously broken in the width direction of the structure (CS-TS-N) (Figure $5(\mathrm{~b}))$.
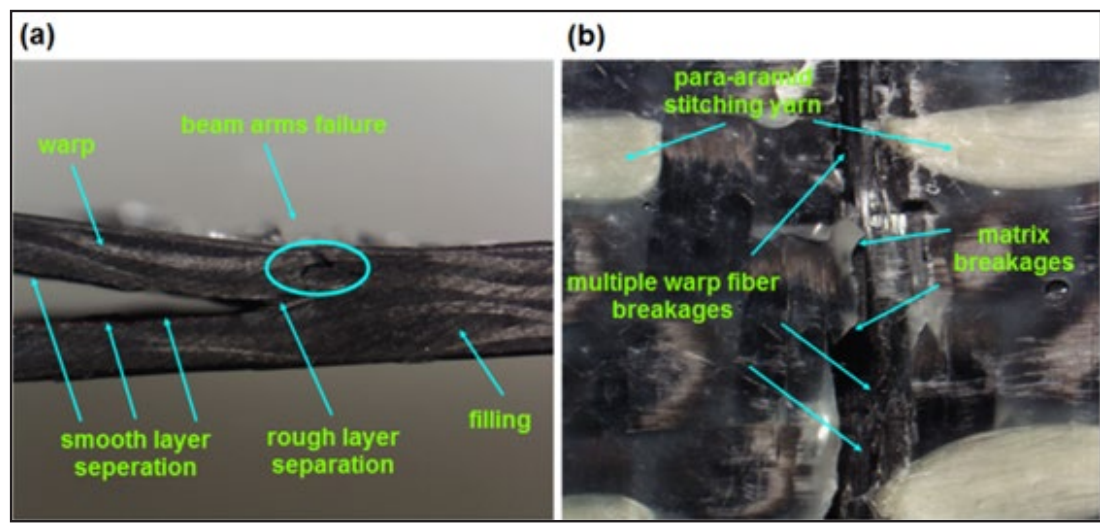

Figure 5 : (a) Beam arms failure in CS-TS-N; (b) top view of severe crack failure during DCB test in CS-TS-N (optical microscope, magnification $\times 6.7)$.

\section{Conclusion}

The mode-I interlaminar fracture toughness (GIC max) of the stitched/nano structures showed an almost 3 fold (283\%, beam theory) and over a 2 fold (225\%, modified beam theory) increase compared to the base or base/nano structures. Stitching and nanotubes increased the fracture toughness strength of all stitched/nano composites. The stitched/nano structure had multiple matrix breakages and multiple brittle tensile filament breakages in the carbon nanostitching yarn where filament/ matrix de-bonding and filament pull-out were observed. In contrast, para-aramid filament bundles in the nanostitching yarn in stitched/nano structures axially split and they had ductile tensile failures and their filaments had axial fibrillar splitting.

\section{References}

1. Khan SU, Kim JK (2011) Impact and delamination failure of multiscale carbon nanotube-fiber reinforced polymer composites: A review. International Journal of Aeronautical and Space Science 12(2): 115133.

2. Thostenson ET, Ren ZF, Chou TW (2001) Advances in the science and technology of carbon nanotube and their composites: A review. Composites Science and Technology 61(3): 1899-1912.

3. Wicks S, Villoria R, Wardle B (2010) Interlaminar and intralaminar reinforcement of composite laminates with aligned carbon nanotubes. Composites Science and Technology 70: 20-28.

4. Bilisik K, Erdogan G, Karaduman N, Sapanci E, Gungor S (2017) Fracture Toughness of Nanostitching/Nano prepreg Carbon/Epoxy Composites. 25th International Conference on Composites or Nano Engineering (ICCE-25) Italy, pp. 1-2. 
(CC) This work is licensed under Creative

(c) Commons Attribution 4.0 Licens

DOI: 10.19080/CTFTTE.2017.01.555557

\section{Your next submission with Juniper Publishers will reach you the below assets}

- Quality Editorial service

- Swift Peer Review

- Reprints availability

- E-prints Service

- Manuscript Podcast for convenient understanding

- Global attainment for your research

- Manuscript accessibility in different formats

( Pdf, E-pub, Full Text, Audio)

- Unceasing customer service

Track the below URL for one-step submission https://juniperpublishers.com/online-submission.php 